\title{
W. F. Libby and the development of radiocarbon dating
}

\author{
RICHARD BURLEIGH
}

\begin{abstract}
The originator of radiocarbon dating, Willard Libby, who died last September, was a distinguished scientist and Nobel laureate whose work has had a profound effect on archaeology over the last 30 years. We asked Richard Burleigh, who is in charge of dating at the Research Laboratory of the British Museum in London and who first met Professor Libby in I962, to give us a brief account of Libby and his work, and he has sent us the following article.
\end{abstract}

Radiocarbon dating is probably the greatest contribution that has been made to archaeology by the physical sciences, and we owe its existence to the genius of Willard Frank Libby, who died in Los Angeles at the age of 71 years on 8 September r980. His death is a loss both to archaeology and, because of the breadth of his scientific interests and achievements, to science at large.

Following Professor Libby's death, obituary notices appeared in several leading newspapers and journals in this country (for example, The Times and The Daily Telegraph of II September 1980; New Scientist, 18 September) and it is therefore necessary to give here only an outline of his career before attempting to assess the effect that his invention of radiocarbon dating has had on prehistoric archaeology.

Born in Colorado in 1908 and brought up in California, Libby studied physical chemistry at the University of California, Berkeley, gaining his Ph.D there in 1933 . He then held appointments at Berkeley and continued his researches there, mainly in nuclear chemistry, until 1941. From 1941-5 at Columbia University, as a part of the Manhattan Project for the development of the atomic bomb, Libby worked on the separation of uranium isotopes by the gaseous diffusion process. After the war he was appointed Professor of Radiochemistry at the University of Chicago, and it was from the Institute for Nuclear Studies there that his paper predicting the occurrence of very small amounts of carbon-14 in living matter appeared (Libby, 1946), the first in a now-classic series by Libby and his later collaborators that laid the foundations of the radiocarbon dating method. In 1959, after a five-year term as a Commissioner of the US Atomic Energy Commission, during which he helped establish the International Atomic Energy Agency in Vienna and was actively concerned with the potential engineering uses of nuclear explosions, Libby was appointed Professor of Physical Chemistry at the University of California, Los Angeles, and in 1962 he became, in addition, Director of the Institute of Geophysics and Planetary Physics at UCLA, both of which appointments he held until his retirement in 1976 . For his pioneering research leading to the development of the radiocarbon dating method, Libby received the Nobel Prize for Chemistry in I960. The history of this research was recounted in his book Radiocarbon dating (1952). In further recognition of his achievements, Libby was made a member of the American Academy of Arts and Sciences and of the National Academy of Sciences, and he received awards and honours from universities and scientific institutions all over the world. His wide-ranging scientific interests made him sought after as an advisor by governmental, industrial and other organizations in the United States.

Beyond his continuing interest in the development and applications of radiocarbon methodology and, in particular, in modelling the dynamics of the processes regulating production and exchange of carbon-I 4 in nature, Libby's other research interests extended over a very wide field, embracing 
the applications of chemistry and chemical methods to lunar and space research, the terrestrial environment, climatic change, pollution control, earthquake protection and civil defence. This eclecticism was well reflected in the programme of a three-day memorial symposium held in Libby's honour at UCLA last December, the topics of which ranged from molecular biology to chemical catalysis, planetary physics, and the increasing concentration of carbon dioxide in the Earth's atmosphere, and even so (to quote from the programme), '... do not represent the full range of interests of this versatile man.' Libby was the author of some 300 refereed and published papers which it is intended to bring together in a two-volume collected edition of his works (Dr Leona Marshall Libby, pers. comm.). Meanwhile, a list of his publications will appear in Radiocarbon.

Libby was always an accessible and willing participant in scientific discussions, both at the International Radiocarbon Conferences held every $3^{-4}$ years, which he attended regularly until the Ioth Conference in 1979 (Antiquity, LIV, I980, I 35-7), and during his personal visits to radiocarbon laboratories. His continuing concern for the work and welfare of these laboratories (of which there are now about I05 in operation) was a source of stimulus and inspiration to many.

The process of formation of carbon-I 4 in the Earth's atmosphere by the interaction of cosmic ray secondary neutrons with nitrogen atoms was known as early as 1940 from the work of S. A. Korff, and studies of carbon- 14 produced artificially in the 6o-inch cyclotron at Berkeley at about the same time had shown that its half-life was of the order of thousands of years. Libby's great inspiration was to see that, since the half-life of carbon-14 was very short in relation to the age of the Earth, a radioactive equilibrium must have long existed in which the rate of production of carbon-r 4 would be matched by its rate of decay. Carbon-14 produced in the atmosphere would be rapidly oxidized to carbon dioxide and become uniformly mixed and distributed throughout the biosphere and the surface of the oceans. From this realization it was evident that uptake of carbon-I4 by plants and animals would cease at death. It was a relatively small logical step from this fact to the idea that, knowing the rate of decay of carbon-14, measurement of the amount remaining in once-living material would allow the time since death to be estimated, so that ancient organic material could be effectively dated in this way. Libby's great contribution was to put this realization into practice by searching for and identifying carbon-14 in contemporary organic matter (and showing, conversely, that geologically ancient carbonaceous material, for example petromethane, contained no measurable carbon-r4), and demonstrating the essential uniformity of the world-wide assay. As the level of carbon-I4 in living matter proved to be very low (about I part in $1^{12}$ parts of ordinary, non-radioactive carbon-12) it was at once apparent that radiochemical procedures and methods of measurement of unprecedented sensitivity would be required for any workable system of dating. By the standards of equipment now in routine use, the system Libby used, though a brilliant solution to problems he was the first to encounter, was relatively insensitive and it is a fortunate irony that this was so. It is quite possible that with more sensitive equipment, the natural carbon-I 4 variations that render calibration of the radiocarbon time scale necessary would have been discovered much sooner, and possibly interpreted as invalidating the method (W. F. Libby, pers. comm., I976).

Today there is a total of about 50,000 published natural radiocarbon measurements, about half of these being archaeological dates and the remainder relating, arnong other fields of application, to Quaternary geology and geomorphology, palaeoecology, hydrology and oceanography. Clearly, however, the most important single application has been to archaeology in the broadest sense on a world-wide scale. Libby published his first formal list of dates in Science in 1951, but as the number of radiocarbon laboratories grew Science could no longer undertake the publication of an increasing number of extensive date lists, and the Radiocarbon Supplement of the American Fournal of Science was established for this purpose in $195^{8}$, becoming plain Radiocarbon in I960. With the proliferation of dating laboratories, so the body of published literature grew as well. In a recent study by Dilette Polach (1979, 1980) of publications in the English language over the first 20 years of radiocarbon dating (1948-68) some 3,000 primary references were retrieved, giving a projected total of about 7,000 publications in 1978 , and evidently this trend continues.

An interesting account of the first faltering beginnings in the relationship between radiocarbon dating and archaeology has been given recently by Marlowe (1980), based on taped interviews with 
Libby and some of the other main participants, and on Libby's correspondence. This account illustrates well the early difficulties and misunderstanding in establishing a technique that was at the time, in Libby's own words '... both highly unusual and unbelievable to even some of the most enlightened individuals' (Marlowe, 1980, I,009). Today, 30 years later, we take for granted the fact that radiocarbon dating has provided a chronometric framework for prehistory and one that has been consolidated rather than weakened by the recognition in the meantime of the need to calibrate the radiocarbon time scale. Now the emphasis is not upon whether radiocarbon dating is or is not a valid means of obtaining an overall chronology, but upon the ultimate resolution that it can be expected to provide, or in other words, the extent to which it can be used to establish the phasing of processes in prehistory. The problems of the chronology of pottery styles within the later bronze age cultures of the British Isles and northwest Europe might be cited as one such example where the broad chronology has been determined, but the sequence and duration of some individual phases may not be determinable. On the other hand, the ability to date the cultural material from earlier periods, for example the Upper Palaeolithic of Europe, is regulated much more by the avail- ability of suitable samples than by any limitations that may be inherent in the method itself.

From its earliest beginnings the radiocarbon field has been multidisciplinary in character, reflecting perhaps the versatility of its originator. In the search for more detailed understanding of the processes on which radiocarbon dating depends, much important new knowledge has been gained about the geophysics and geochemistry of the atmosphere and the oceans. It was Libby's firm view that this knowledge, combined with the specialized facilities of the world-wide network of radiocarbon laboratories, should be used to practical effect in ways additional to dating. In particular he saw as a most urgent problem for mankind, the possibility of adverse climatic change (warming) being brought about by the increasing concentration of carbon dioxide in the Earth's atmosphere, the so-called 'greenhouse effect'. Libby urged that radiocarbon methodology can contribute significantly to investigation of the reality or otherwise of this danger.

With the advent of accelerator methods the amount of material required for dating will be reduced one-thousandfold to a few milligrams of carbon and the far age limit attainable may be doubled, to 100,000 radiocarbon years before present. It is a re-affirmation of the significance of Libby's original discovery that such advances are still being made.

\section{BIBLIOGRAPHY}

LIBBY, W. F. I 946. Atmospheric helium three and radiocarbon from cosmic radiation, Physical Review, LxIX, 67I-2.

1952. Radiocarbon dating (Chicago).

MARLOWE, G. 1980. W. F. Libby and the archaeologists, 1946-1948. Radiocarbon, XXII, 1,005-14.
POLACH, D. 1979. First 20 years of radiocarbon dating : an annotated bibliography, $1948-68$ (Canberra).

1980 . The first 20 years of radiocarbon dating: an annotated bibliography, I 948-68; a pilot study, Radiocarbon, xxil, 997-1,004.

\section{Book Chronicle}

We include here books which have been received for review, or books of importance (not received for review) of which we have recently been informed. We welcome information about books, particularly in languages other than English, of interest to readers of ANTIQUITY. The listing of a book in this chronicle does not preclude its review in ANTIQUITY.

Excavaciones en El Cabezo de San Pedro (Huelva). Campaña de r977, by J. M. Blázquez Martinez, D. Ruis Mata, J. Remesal Rodrigues, J. L. Ramirez Sadaba \& K. Clauss. Excavaciones Arqueologicas en España. Madrid: Ministerio de Cultura, 1979. 200 pp., illustrated.

Who was who in the Roman World 753 BCAD 477 edited by Diana Bowder. Oxford: Phaidon, r980. 256 pp., illustrated. $£ 8.95$.
Führer zu vor-und frühgeschichtlichen Denkmälern. Koln $x, 2$ : Museen in Köln. by $\mathrm{H}$. Borger et al. Mainz: Philipp von Zabern, I98o. I03 pp., 23 illustrations, II loose maps in folder.

Castulo II by José Mária Blázquez. Excavaciones Arqueologicas en España. Madrid: Ministerio de Cultura, $1979.45^{\circ}$ pp., 186 figs., 59 pls., 20 pullout plans.

continued on P. II4 